\section{Basic Forestry Facts}

The CIF is presently working to lobby and inform elected officials in the provincial legislatures and the federal parliament. The objective is to establish a better understanding of Canadian forestry imperatives and to keep elected members informed on a continuing basis.

The Canadian Forestry Association has compiled a fact sheet to be used in public information programs. With the permission and encouragement of the CFA, the fact sheet is published here to serve CIF members in their lobby efforts. Subsequent issues of The Forestry Chronicle will carry updated forestry facts as new information is acquired.

1. Forest industry employed 310000 people directly and paid out $\$ 5.6$ billion in salaries (1979). About 700000 additional people worked in service or associated jobs.

2. Value of Canadian forest products shipments (1980) was $\$ 22.1$ billion. Exports alone in 1980 had a total value of $\$ 12.8$ billion.

3. Balance of trade (to primary level of manufacture only) $\$ 000,000$.

$\begin{array}{rrrrrr}\text { Year } & \begin{array}{c}\text { Forest } \\ \text { Industry }\end{array} & \text { Fishing } & \text { Agriculture } & \text { Mining } & \text { Fuels } \\ 1978 & 8409 & 861 & 1578 & 4551 & 413 \\ 1979 & 10344 & 981 & 1704 & 4536 & 783 \\ 1980 & 11500 & & & & \end{array}$

4. Forest industry generated $\$ 1.7$ billion for provincial governments and $\$ 1.3$ billion for the federal government in corporate taxes, charges and taxes on direct employees (1979) - a total of $\$ 3$ billion annually.

5. There are $300000-400000$ private owners of small forest properties in Canada which supply substantial amounts of wood to local industry.

6. Healthy forests are basic to Canada's multi-billion dollar outdoor recreation industry.

7. About 800000 hectares of forest land are harvested each year in Canada.

8. Annually, some 200000 hectares are artificially planted or seeded, 200000 to 300000 hectares regenerate reasonably well naturally, and the remaining lies idle for a time or reverts indefinitely to non-commercial weed trees and scrub.

9. Canada's reforestation effort should be raised from 200000 hectares to 700000 hectares annually to cope with the current regeneration gap and to reduce the backlog (over 20 million hectares) of neglected land which is on productive sites near existing communities.

10. Silvicultural treatments such as weeding, juvenile spacing and fertilizing to increase yield from existing young forests should be increased annually from the present 100000 hectares to 400000 hectares.

11. Present costs of existing artificial regeneration (200 000 hectares annually \#8) and stand improvement (100 000 hectares \#10) amounted to $\$ 230$ million in 1981. The forest renewal effort will require that this be increased by 3 to 4 times in the next few years.

12. The average annual losses of merchantable wood from fire, insects and disease are estimated at 100 million cubic metres, or nearly two-thirds of the volume harvested annually. In 1980 and 1981 this loss was much greater because of historically high fire losses.

13. Increases in investment (see \#11) have immediate positive effects on the economy and provide even greater benefits in the long run from growing better wood, faster, with higher yields per acre. This investment is essential if the forest resource is to retain its prominence in Canada's economy.

14. In spite of greater expenditures in recent years in forestry by governments and industry there must be increased investment for healthy and productive forests before the deterioration of Canada's forest estate will be reversed.

\section{For the Sake of Argument: Canada Does Not Need More Forest Research Now - It Needs More Forestry}

History has repeated itself over the last 10 to 20 years with periodic outpourings about the parlous state of Canadian forest research. We have had high-powered reports and reviews and most recently a form of think-tank sponsored by PPRIC. The unanimous conclusion has been Canada needs more forest research.

For the sake of argument, I propose that Canada neither needs nor deserves more forest research now; we need to start practicing forestry first or, as a concession to those few candles in the gloom, we need to practice to the level of current knowledge before this plea becomes urgent.

What we need nationally and provincially is commitment and action plans to implement the motherhood conclusions of the big-name, ongoing conferences and meetings of Canadian resource and environment ministers. Their only real, current contribution to the furtherance of Canadian prosperity appears to be that the paper use they generate all helps to make that Canadian forest an "endangered species," and brings us closer to desperate measures in our dire straits.

Once we get forest management beyond the kindergarten level, practicing foresters will (hopefully) begin to realize the limits of this knowledge and will identify the truly necessary research to resolve their problems - silvical, ecological, financial and political. Then we will get research done where it is needed on a priority need-to-know basis to provide answers to people who will use it and who will ensure it is goal-oriented.

Until that happy stage is reached all our research staff should stop publishing unwanted and unread reports; reports of primary value only to their fellow scientists who will then quote these scientifically pure but impracticable results in their own research papers and so ad infinitum. Rather let them take to the highways and byways and impart their knowledge to the poor peons in the forest fields and also prepare themselves at first hand for the big job that awaits them.

Who am I? A benched research manager growing impatient and irascible with advancing years at our snail-like progress. What do you think? How about some noise?

\section{kbm FORESTRY CONSULTANTS INC.}

\author{
360 MOONEY STREET \\ THUNDER BAY, ONTARIO \\ P7B 5R4 \\ TEL.: 344-0811
}

